\title{
The Antecedents of the Consumers' Mobile Learning Intention during the Covid-19 Pandemic
}

\author{
Ece Armağan ${ }^{1}$, Esma Durukal ${ }^{1}$ \\ ${ }^{1}$ Nazilli Faculty of Economics and Administrative Sciences, Aydin Adnan Menderes University, Aydin-Turkey.
}

Corresponding author; earmagan@adu.edu.tr

Received: 23, August, 2021

Accepted: 01, September, 2021

Published: 16 September 2021

\begin{abstract}
Purpose Covid-19, which affects the whole world, has caused serious changes in many aspects such as lifestyle, habits and purchasing behaviour. New digital consumers and companies that emerged during the epidemic; they realized that mobile devices, especially mobile phones, have become a solution to many real-world problems such as learning and education anytime and anywhere. This study aims to determine the factors affecting the users' mobile learning (m-learning) usage intention during the Covid-19 pandemic process.

Design/methodology/approach - This study contributed to the confirmation of the extended TAM model for a mobile device. The sample of the questionnaire is 460 students from different universities in Turkey. These data obtained were analyzed with the Structural Equation Model (SEM) and LISREL program was used for data analysis.

Findings - This study proffers a model that the antecedents of the users' mobile learning intention during the Covid-19 pandemic. According to the results of the study, it was concluded that the factor affecting the users' mobile learning (m-learning) intention to use the most is perceived ease of use, the least effective factor is intrinsic leisure motivation, and the future anxiety factor has a meaningless effect.

Originality/value - A holistic view of the antecedents of the users' mobile learning intention during the Covid-19 pandemic would be of important use to practitioners and academics alike. This study is different from previous studies; It is thought that it will contribute to the literature by addressing the effects of internal leisure motivation, future anxiety, behavioural spread and system-service quality dimensions on $\mathrm{m}$-learning. For the researchers, this study took an important step towards explaining the m-learning relationship with students' intrinsic leisure motivation, future anxiety, behavioural spread, and system-service quality learning perspectives.
\end{abstract}

Keywords Mobile learning, Mobile CRM, Technology Acceptance Model

\section{Introduction}

While the first Covid-19 cases in the world emerge in Wuhan, China, has been seen on March 11, 2020, in Turkey. The Covid-19 pandemic process that started after this date affects the whole world in many aspects such as economic, cultural and technology. In this process, where the primary aim is to survive, it is seen that the minor behaviour patterns of the consumers emerge and their habits change. Besides, it is possible to say that the consumer behaves more rationally and tends towards more rational products that will meet his needs. In brief, there has been a rapid transition to a more digital era where even hobbies differ.

The mobile industry shows rapid growth in both developed and developing countries with a steadily increasing rate of personal ownership [27]. The mobile industry contributes to people's lives and work, thanks to its wider accessibility to the mobile cellular network [25]. Also, it is more involved in daily life at the global level [27]. Wireless technology has become one of the most common functional tools used in everyday life, providing widen mobility for a permanently "connected" lifestyle [25]. The widespread use of mobile devices has also affected the field of education, and learning tools have started to adapt to digital transformation. Mobile devices are seen as technologies that are likely to affect the education sector and learning with their high market penetration and constantly evolving technological features [27].

The demand for m-learning applications and the popularity of the applications are increasing rapidly. With the implementation of many projects on m-learning, it has become a common phenomenon in modern education systems [2]. M-learning is an innovative idea that provides tremendous opportunities by connecting people and technology, such as better learning experiences and technology adoption. The use of M-learning is increasing rapidly around the world, but there are some deficiencies in understanding the factors that affect its acceptance in society, especially in developing countries [11]. It is very significant for the successful application of m-learning systems to be accepted by individuals [53]. Also, to encourage the use of technological innovations, potential users must first be made aware of the technology and persuade its use. Understanding the various factors affecting technology adoption is at the centre of technology 
adoption research [26]. So, there is a need to investigate the factors affecting the user's intention to use m-learning [53].

There are plenty studies in marketing literature about behavioural intention and use in using m-learning [26]; [12]; [5]; [25]; [2]; [6]; [1]; [42]; [30]; [16]; [11]; [8]; [44]; [13]; [37]; [43]; [27]; [38]; [9]; [23]; [22]; [47]; [4]; [14]; [3]; [48]; [10]; [51]; [34]; [31]; [53]. In these studies, the Technology Acceptance Model (TAM), Unified Theory of Acceptance and Use of Technology (UTAUT), and Unified Theory of Acceptance and Use of Technology (UTAUT2) are generally used as basic models. This study sets out a framework for the adoption of m-learning services. The variables that affect the participants' intention to use mlearning services were determined by the integration of variables derived from the TAM. The aim of this study is; to determine the factors that affect the users' intention to use m-learning during the Covid-19 pandemic process. And then, it is aimed to suggest strategies to companies about mobile CRM with the results. This study is different from previous studies; It is thought that it will not contribute to the literature by addressing the effects of internal leisure motivation, future anxiety, behavioural spread and systemservice quality dimensions on m-learning.

\section{Literature review}

This section is about a brief review of relating to our work.

\subsection{Mobile learning}

Mobile applications (used in tools such as smartphones and tablets) have emerged in the business world as a marketing tool, primarily because they change customer-company interaction models [49]. With the spread of mobile computing technology, m-learning plays a major role in the rapidly growing electronic learning market. Mlearning enables individuals to deliver learning anytime and anywhere through the use of wireless internet and mobile devices, including tablets, personal digital assistants (PDAs), smartphones and digital audio players [53]. M-learning is defined as learning about the user's mobility where information can be managed personally using mobile applications [12]. Defined as a variation of e-learning in early studies, m-learning enables learning anytime and anywhere with the use of mobile devices or handheld information technology (IT) devices. M-learning occurs when individuals participate in learning activities regardless of a physical location. Recent studies provide a broader definition of m-learning and define it as "learning in multiple contexts using personal electronic devices, through social and content interactions" [38]. Potential benefits of m-learning include a wide range of cost savings, comprehensive communication and location-based services [47]. Among the reasons for the rapid growth of $\mathrm{m}$ learning are the increase in the number of mobile devices, low cost of mobile services, the rapid development of mobile wireless technologies, capability improvements of mobile devices and SMS, MMS, voice/video recording, picture capture, data storage and internet access [39]. The evolution of educational methods in organizations is leading to new technology-based learning models [25].

M-learning has recently turned into a real educational platform. This is evidenced by the growth and impact of breakthrough technology and the application of m-learning over the last decade. The growth and development of m-learning have also been in keeping with the evolution of the online world. Also, the rapid development of mobile technology has encouraged the creation of wireless m-learning in mobile devices. Moreover, parallel to the development of communication tools, the learning process is evolving from the traditional face-to-face method to distance learning and e-learning [23]. In particular, the increase in the use of smartphones as a learning tool in education causes the rapid spread of m-learning in both developed and developing countries. The key features of smartphones, namely mobility, ubiquity, lightness, low cost and connectivity anywhere and anytime, enhance their use in a variety of ways.

M-learning creates an important advantage for institution staff as well as students. So, it is extremely important for both the business world and the training and development of students. Education is recognized as an essential strategic organizational tool and is also associated with greater profit and employee retention. However, staff training was generally seen as a cost rather than an investment. This idea has changed today with the understanding that education is now an important factor in creating knowledge and therefore one of the most valuable business-related activities. In a dynamic and ever-changing environment, companies need to keep employees' knowledge and necessary skills constantly up-todate to remain competitive. The reason why institutions and organizations invest in education is that a qualified and educated workforce will provide more added value as well as making their jobs sustainable and competitive [25]. M-learning is one of the most advantageous applications in today's conditions. Studies on m-learning in the literature are presented in Table 1 .

Table 1 Studies on the acceptance of the use of mobile learning

\begin{tabular}{|c|c|c|c|}
\hline Reference & Data Source & Dimensions & External Variables \\
\hline Al-Emran et al. (2020) & $\begin{array}{l}\text { Malaysia, } 416 \\
\text { university students }\end{array}$ & $\begin{array}{l}\text { Perceived usefulness, perceived ease of use, } \\
\text { knowledge acquisition, knowledge sharing, } \\
\text { knowledge application, knowledge } \\
\text { protection }\end{array}$ & $\begin{array}{l}\text { Behaviour intention to use, } \\
\text { actual system use }\end{array}$ \\
\hline Hoi (2020) & $\begin{array}{l}\text { Vietnam, } 293 \\
\text { university students }\end{array}$ & $\begin{array}{l}\text { Performance expectancy, effort expectancy, } \\
\text { social influence, facilitating conditions }\end{array}$ & $\begin{array}{l}\text { Attitude, behavioural } \\
\text { intention, use behaviour }\end{array}$ \\
\hline Aliaño et al. (2019) & $\begin{array}{l}\text { Spain, } 370 \\
\text { university students }\end{array}$ & $\begin{array}{l}\text { Performance Expectancy, Effort } \\
\text { Expectancy, Social Influence, Voluntariness } \\
\text { to Use, Facilitating Conditions, Self- } \\
\text { management of Learning, Perceived } \\
\text { Gratification }\end{array}$ & Behaviour intention \\
\hline
\end{tabular}




\begin{tabular}{|c|c|c|c|}
\hline García et al. (2019) & $\begin{array}{l}\text { Spain, companies' } \\
\text { employees }\end{array}$ & $\begin{array}{l}\text { Perceived usefulness, perceived ease of use, } \\
\text { Image, Subjective norm, voluntariness, job } \\
\text { relevance, output quality, result } \\
\text { demonstrability, self-efficacy, perceptions of } \\
\text { external control, anxiety, playfulness, } \\
\text { perceived enjoyment }\end{array}$ & $\begin{array}{l}\text { Behaviour intention m- } \\
\text { learning acceptance }\end{array}$ \\
\hline Chavoshi and Hamidi (2019) & $\begin{array}{l}\text { Iran, } 388 \text { university } \\
\text { students }\end{array}$ & $\begin{array}{l}\text { Pedagogical, technological, social and } \\
\text { individual factors, Performance expectancy, } \\
\text { effort expectancy, social influence, } \\
\text { facilitating conditions, perceived usefulness, } \\
\text { perceived ease of use }\end{array}$ & $\begin{array}{l}\text { Behaviour intention, } \\
\text { Behaviour intention to use }\end{array}$ \\
\hline Arain et al. (2019) & $\begin{array}{l}\text { Pakistan, } 730 \\
\text { university students }\end{array}$ & $\begin{array}{l}\text { Performance expectancy, effort expectancy, } \\
\text { social influence, facilitating conditions, } \\
\text { hedonic motivation, habit, ubiquity, } \\
\text { information quality, system quality, } \\
\text { appearance quality }\end{array}$ & $\begin{array}{l}\text { Behaviour intention, } \\
\text { satisfaction }\end{array}$ \\
\hline Huang et al. (2019) & $\begin{array}{l}\text { Taiwan, } 335 \\
\text { students }\end{array}$ & $\begin{array}{l}\text { Perceived usefulness, perceived flexibility } \\
\text { advantage, personal innovativeness, } \\
\text { perceived playfulness, self-management of } \\
\text { learning, perceived fit }\end{array}$ & $\begin{array}{l}\text { M-learning continuance } \\
\text { intention }\end{array}$ \\
\hline Saroia and Gao 2019 & $\begin{array}{l}\text { Sweden, } 130 \\
\text { university students }\end{array}$ & $\begin{array}{l}\text { Perceived usefulness, perceived ease of use, } \\
\text { perceived mobility value, academic } \\
\text { relevance, university management support }\end{array}$ & $\begin{array}{l}\text { Attitude toward usage, } \\
\text { behaviour intention to use }\end{array}$ \\
\hline Almaiah et al. (2019) & $\begin{array}{l}\text { Jordan, } 697 \\
\text { university students }\end{array}$ & $\begin{array}{l}\text { Performance expectancy, effort expectancy, } \\
\text { social influence, facilitating conditions, } \\
\text { perceived compatibility, self-efficacy, } \\
\text { perceived information quality, availability of } \\
\text { resources, perceived awareness, perceived } \\
\text { trust }\end{array}$ & $\begin{array}{l}\text { Behaviour intention to use, } \\
\text { actual use m-learning }\end{array}$ \\
\hline Aloqaily et al. (2019) & $\begin{array}{l}\text { Jordan, } 167 \\
\text { university students }\end{array}$ & $\begin{array}{l}\text { Performance expectancy, effort expectancy, } \\
\text { social influence, facilitating conditions }\end{array}$ & Behaviour intention \\
\hline Alasmari and Zhang, (2019) & $\begin{array}{l}\text { Saudi Arabian, } \\
1203 \text { university } \\
\text { students }\end{array}$ & $\begin{array}{l}\text { Learning expectancy, effort expectancy, } \\
\text { social influence, facilitating conditions, m- } \\
\text { learning technology characteristics, self- } \\
\text { management of learning, }\end{array}$ & $\begin{array}{l}\text { Behaviour intention, use } \\
\text { behaviour of m-learning }\end{array}$ \\
\hline Alshurideh et al. (2019) & $\begin{array}{l}\text { The United Arab } \\
\text { Emirates, } 221 \\
\text { university students }\end{array}$ & $\begin{array}{l}\text { Perceived usefulness, perceived ease of use, } \\
\text { quality of the system, information quality, } \\
\text { content quality, service quality }\end{array}$ & Intention to use \\
\hline Senaratne and Samarasinghe, (2019) & $\begin{array}{l}\text { Sri Lanka, } 151 \\
\text { graduate student }\end{array}$ & $\begin{array}{l}\text { Perceived usefulness, perceived ease of use, } \\
\text { mobile self-efficacy, system quality, } \\
\text { intrinsic motivation }\end{array}$ & $\begin{array}{l}\text { Behaviour intention to } \\
\text { adopt }\end{array}$ \\
\hline Al-Shihi et al. (2018) & $\begin{array}{l}\text { Oman } 388, \\
\text { university students }\end{array}$ & $\begin{array}{l}\text { Social learning, flexibility learning, } \\
\text { enjoyment learning, suitability learning, } \\
\text { efficiency learning, economic learning }\end{array}$ & M-learning acceptance \\
\hline Park et al. (2018) & $\begin{array}{l}\text { South Korean, } 557 \\
\text { university students }\end{array}$ & $\begin{array}{lcr}\text { Relative } \quad \text { advantage, } & \text { compatibility, } \\
\text { complexity, } \quad \text { observability, } & \text { trialability, } \\
\text { system quality, resistance } & \end{array}$ & M-learning acceptance \\
\hline Sharma et al. (2017) & $\begin{array}{l}\text { Oman } 806, \\
\text { university students }\end{array}$ & $\begin{array}{l}\text { Flexibility, suitability, enjoyment, } \\
\text { efficiency, economics, social }\end{array}$ & M-learning acceptance \\
\hline Hao et al. (2017) & $\begin{array}{l}\text { China } 292, \\
\text { university students }\end{array}$ & $\begin{array}{l}\text { Image, Subjective norm, voluntariness, } \\
\text { perceived facilitation, innovativeness, } \\
\text { perceived usefulness, perceived ease of use }\end{array}$ & Behaviour intention \\
\hline Poong et al. (2017) & $\begin{array}{l}\text { Luang Prabang } \\
\text { City, } 349 \text { university } \\
\text { students }\end{array}$ & $\begin{array}{l}\text { Social influence, self-efficacy, perceived } \\
\text { enjoyment, personal innovativeness, } \\
\text { perceived usefulness, perceived ease of use }\end{array}$ & Behaviour intention to use \\
\hline Altrad, (2017) & $\begin{array}{l}\text { Malaysia, } 384 \\
\text { university students }\end{array}$ & $\begin{array}{l}\text { Perceived usefulness, perceived ease of use, } \\
\text { student readiness, culture factors, cost of } \\
\text { service, compatibility }\end{array}$ & $\begin{array}{l}\text { Behavioural intention, use } \\
\text { behaviour }\end{array}$ \\
\hline El-Ebiary et al. (2017) & $\begin{array}{l}\text { Malaysia, } 500 \\
\text { university students }\end{array}$ & $\begin{array}{l}\text { Perceived usefulness, perceived ease of use, } \\
\text { service quality, culture }\end{array}$ & Behaviour intention \\
\hline
\end{tabular}




\begin{tabular}{|c|c|c|c|}
\hline Edwards 2017 & University students & $\begin{array}{l}\text { Performance expectancy, effort expectancy, } \\
\text { social influence, facilitating conditions, } \\
\text { hedonic motivation, habit. }\end{array}$ & Behaviour intention to use \\
\hline Tavallaee et al. 2017 & $\begin{array}{l}\text { Tehran, } 170 \\
\text { university students }\end{array}$ & $\begin{array}{l}\text { Perceived usefulness, perceived ease of use, } \\
\text { compatibility, peer influence, superior's } \\
\text { influence, perceived behavioural control, } \\
\text { self-efficacy, subjective norm }\end{array}$ & $\begin{array}{l}\text { Behaviour intention, actual } \\
\text { behaviour }\end{array}$ \\
\hline Ali ve Arshad, 2016 & Egypt students & $\begin{array}{l}\text { Performance expectancy, effort expectancy, } \\
\text { social influence, facilitating conditions, } \\
\text { mobility, interactivity, enjoyment }\end{array}$ & Behaviour intention \\
\hline Al-Zoubi, 2016 & $\begin{array}{l}\text { Dubai, } 395 \\
\text { undergraduate and } \\
\text { graduate students }\end{array}$ & $\begin{array}{l}\text { Perceived usefulness, perceived ease of use, } \\
\text { service quality, student readiness, trust } \\
\text { factor, compatibility }\end{array}$ & Behaviour intention, to use \\
\hline Almaiah et al.2016 & $\begin{array}{l}\text { Jordan, } 392 \\
\text { participants }\end{array}$ & $\begin{array}{l}\text { Learning content quality, content design } \\
\text { quality, interactivity, functionality, user- } \\
\text { interface design, accessibility, availability, } \\
\text { personalization, responsiveness, perceived } \\
\text { usefulness, perceived ease of use }\end{array}$ & Behaviour intention to use \\
\hline Uğur et al. (2016) & $\begin{array}{l}\text { Turkey, } 491 \\
\text { university students }\end{array}$ & $\begin{array}{l}\text { Performance expectancy, effort expectancy, } \\
\text { social influence, facilitating conditions, self- } \\
\text { management of learning }\end{array}$ & Behaviour intention \\
\hline Aofan et al. (2016) & $\begin{array}{l}\text { China, } 186 \\
\text { university students }\end{array}$ & $\begin{array}{l}\text { Performance expectation, effort expectation, } \\
\text { social impact, success value, perceived } \\
\text { volatility, self-management }\end{array}$ & Behaviour intention \\
\hline Yeap et al. (2016) & $\begin{array}{l}\text { Malaysia, } 900 \\
\text { university students }\end{array}$ & $\begin{array}{l}\text { Perceived usefulness, perceived ease of use, } \\
\text { instructor readiness, student readiness, } \\
\text { perceived self-efficacy, learning autonomy, } \\
\text { subjective nom, perceived behavioural } \\
\text { control }\end{array}$ & Intention to adopt \\
\hline Mutono and Dagada, (2016) & $\begin{array}{l}\text { South Africa, } 384 \\
\text { university students }\end{array}$ & $\begin{array}{l}\text { Performance expectancy, effort expectancy, } \\
\text { social influence, facilitating conditions }\end{array}$ & $\begin{array}{l}\text { Behaviour intention, } \\
\text { attitude toward behaviour }\end{array}$ \\
\hline Kang et al. (2015) & $\begin{array}{l}\text { Korea, } 305 \\
\text { university students }\end{array}$ & $\begin{array}{l}\text { Performance expectancy, effort expectancy, } \\
\text { social influence, facilitating conditions, } \\
\text { hedonic motivation, price value, habit. }\end{array}$ & Behaviour intention to use \\
\hline Wang et al. (2009) & $\begin{array}{l}\text { Taiwan, } 330 \\
\text { exhibitors }\end{array}$ & $\begin{array}{l}\text { Performance expectancy, effort expectancy, } \\
\text { social influence, perceived playfulness, self- } \\
\text { management of learning }\end{array}$ & Behaviour intention to use \\
\hline
\end{tabular}

\subsection{Mobile learning with TAM}

Various models have been developed to test users' attitudes and intentions to adopt new technologies or information systems. Among these models, TAM [18], Planned Behaviour Theory (TPB) (Ajzen, 1991), Innovation Diffusion Theory (IDT) (Rogers, 1995) and UTAUT [50]. Among the different models proposed, TAM, an extension of Theory of Reasoned Action (TRA) (Fishbein and Ajzen, 1975), has been a key model in understanding the predictors of human behaviour towards the potential acceptance of technology [42]. TAM is among the most effective models in the information systems literature to predict the adoption and usage behaviour of information technologies by users. Besides, TAM physically groups multiple items that measure each structure. It is the TAM used to direct resource allocation and investment decisions regarding the development and adoption of new and emerging information technologies [19]. The TAM is a widely used model for predicting technology acceptance, proposed for estimating the acceptability of technology variables. While the level of belief that using certain technology will improve jobs is related to the perceived usefulness; perceived ease of use means that the accepted technology is easily understood from users or effortless demand [45].
Although the TAM was originally conceived as a model to explain users' adoption of technology in business and commercial settings, it is further explored as an appropriate research model set in the educational context [42]. [36] emphasize that TAM helps to understand m-learning acceptance dynamics.

\section{Behavioural spread}

As it is known, people interact with each other in society and they change their behaviour to some extent according to the people they see with significant or similar social status. Social impact plays a significant role in influencing the perceptions of potential adopters [38]. The term 'peer group' includes a friendly group of people who regularly interact with each other. Interactions between friends and information sharing mechanisms can eventually turn into peer effects on each other. During the use of technology, if colleagues and close friends adopt a particular technology, peer pressure increases to do the same [49]. So, the relationship between behavioural spread, which is considered as a combination of social and peer effects, and m-learning, is stated with the following hypothesis:

H1: Behavioural spread positively affects perceived usefulness of m-learning. 


\section{Self-management of learning}

Self-management of learning is expressed as the extent to which an individual can discipline himself and participate in autonomous learning [30] and the degree of engagement. The need for selfdirection or self-directed learning is obvious in the literature of distance education and resource-based flexible learning. Since mlearning can be thought of as a type of e-learning via mobile devices, a person's level of self-learning is expected to have a positive effect on behavioural intention to use m-learning [53]. In m-learning environments, individuals must be highly self-directed to be successful, including tasks such as developing critical thinking, setting learning goals, evaluating learning resources, and self-assessment [1]. In this context, the following hypothesis is suggested in the study:

H2: Self-management of learning positively affects perceived usefulness of m-learning.

\section{Intrinsic leisure motivation}

Intrinsic leisure motivation is a significant element based on the time spent, effort and pleasure derived from the process in reaching the determined targets. Intrinsic leisure motivation can be used effectively and efficiently to be clear the psychological and sociological factors that underlie participation in leisure activities. Clarification of the internal causes of leisure time behaviours of individuals is also expressed as an important factor for recreational services providers to develop their existing programs in line with the needs and tendencies of individuals [35]. So, it was thought that it would be important to include this hypothesis in the research for the Covid-19 pandemic process, and the following hypothesis was added to the study:

H3: Intrinsic leisure motivation positively affects perceived usefulness of m-learning.

Future anxiety

Future anxiety refers to attitudes towards the future in which negative cognitive and emotional processes outweigh positive ones and fear is stronger than hope. In other words, it is the fear of future events and the feeling that dangerous or negative changes may occur in the future. It points to a distant rather than a close perspective, as well as a personal preoccupation with possible or anticipated negative changes in the future and people seem to be aware of this [52]. In this regard, during the Covid-19 pandemic process, it was thought that individuals' concerns about the future would come to the fore, and the hypothesis linking future anxiety and m-learning in the study is presented below:

\section{H4: Future anxiety positively affects perceived usefulness of m- learning. \\ Perceived enjoyment}

Those who like to use a system or find it pleasant will use it because it provides satisfaction in the use of that system without any effort. So, individuals who like m-learning will perceive it as easy to use and develop a positive attitude towards its use [25]. Therefore, the relationship between perceived enjoyment and $\mathrm{m}$ learning discussed in the research is shown with the following hypothesis:

H5: Perceived enjoyment positively affects perceived ease of use of m-learning.

\section{Service-system quality}

System and service quality are strongly related to users' perception of technology. The effect of system and service quality on the intended use is present in mobile technologies and online social networks [28]. Therefore, the relationship between service-system quality and m-learning is shown with the following hypothesis:

H6: Service-system quality positively affects perceived ease of use of m-learning.

Perceived ease of use

Even if potential users believe that a particular application is beneficial, they may find that the systems are too difficult to use and that the application's effort to use outweighs the performance benefits of its use. So, in addition to usefulness, it is theorized to be affected by ease of use. Perceived ease of use refers to "the degree to which one believes using a particular system will be effortless." All else being equal, it is claimed that an application perceived as easier to use is more likely to be accepted by the user [18].

\section{H7: Perceived ease of use positively affects perceived usefulness of m-learning.}

\section{Perceived usefulness}

Individuals tend to use or not use an app to the extent that they believe it will make it easier for them to do their job better. The perceived usefulness is defined as "the level of believing that using a certain system will increase job performance". Organizationally, people are often empowered for good performance with upgrades, promotions, bonuses and other rewards. A good system in terms of perceived usefulness is a system in which a user believes there is a positive use-performance relationship [18]. In this context, the following hypotheses are included in the study:

\section{H8: Perceived ease of use positively affects behavioural intention to use mobile learning. \\ Behavioural intention}

Behavioural intention is expressed as "a measure of the strength of an individual's intention to perform a certain behaviour" and is seen as a significant criterion for users to accept the use behaviour [50]. While it is not very important how easy it is to use a system or how attractive the design is, it is stated that it will not be preferred unless it is useful [25]. In this context, the following hypothesis is suggested in the study:

H9: Perceived usefulness positively affects behavioural intention to use m-learning.

\section{Methods}

This section introduces the questionnaire design, model constructs, research model and analysis.

\subsection{Questionnaire design and model constructs}

Research universe, constitute users benefiting from m-learning in Turkey. It is stated that a data set of at least 300 or more is good sample size for factor analysis [46]. In this study, college students in some universities in Turkey constitute the sample. 480 students participated in the study. The opinions of the participants regarding the m-learning services included in the questionnaire question form are given in Table 2 .

Table 2 Opinions of the participants about m-learning

\begin{tabular}{|l|l|l|l|}
\hline & Variables & Frequency & Percentage \\
\hline What are your thoughts on m-learning after 15 & I never knew & 71 & $14.8 \%$ \\
\hline
\end{tabular}




\begin{tabular}{|c|c|c|c|}
\hline March Stayhome? & $\begin{array}{l}\text { I realized I needed training } \\
\text { Need to improve myself has arisen } \\
\text { I decided to study because I have free } \\
\text { time }\end{array}$ & $\begin{array}{l}102 \\
246 \\
211\end{array}$ & $\begin{array}{l}21.3 \% \\
51.2 \% \\
44.0 \%\end{array}$ \\
\hline \multirow{4}{*}{$\begin{array}{l}\text { How long have you been using m-learning } \\
\text { services? }\end{array}$} & Less than 1 year & 233 & $48.5 \%$ \\
\hline & $1-2$ years & 56 & $11.7 \%$ \\
\hline & 3-4 years & 72 & $15.0 \%$ \\
\hline & $\begin{array}{l}5-6 \text { years } \\
7 \text { years and above }\end{array}$ & $\begin{array}{l}54 \\
78\end{array}$ & $\begin{array}{l}11.3 \% \\
16.3 \%\end{array}$ \\
\hline \multirow{11}{*}{$\begin{array}{l}\text { Which trainings did you prefer while using } \mathrm{m} \text { - } \\
\text { learning services? }\end{array}$} & Self-improvement & 235 & $48.90 \%$ \\
\hline & Foreign language & 254 & $52.90 \%$ \\
\hline & Business life & 134 & $27.91 \%$ \\
\hline & Sales and marketing & 106 & $22.10 \%$ \\
\hline & Financial accounting & 114 & $23.80 \%$ \\
\hline & Business & 107 & $22.20 \%$ \\
\hline & Family, health, life & 228 & $47.50 \%$ \\
\hline & Information technology & 116 & $24.20 \%$ \\
\hline & Human resources management & 88 & $18.30 \%$ \\
\hline & Communication & 126 & $26.30 \%$ \\
\hline & Hobbies & 225 & $46.90 \%$ \\
\hline
\end{tabular}

The survey consists of 46 items in total. A 5-point Likert scale; disagree strongly - agree strongly was used to measure all of the scales. The behavioural spread variable was adapted from [38]; [49]; [47] studies. The self-management of learning was adapted from [53]. The future anxiety was adapted from [52], perceived enjoyment [20]; [25]; [38], perceived usefulness [18]; [21]; [25]; [47]; [12], service-system quality [28], perceived ease of use [18]; [21]; [47]; [12]. The behavioural intention was adapted from [53]; [12]; [26] (see Table 3).

\section{Table 3 Model constructs}

\begin{tabular}{|l|l|}
\hline Constructs & Measurement \\
\hline Behavioural spread (BS) & Adapted from Poong et al. (2017); Vahdat et al. 2020; Tavallaee et al. 2017 \\
\hline Self-management of learning (PE) & Adapted from Wang et al. 2009 \\
\hline Intrinsic leisure motivation (AU) & Adapted from Mutlu, 2008; Özdemir et al. 2020 \\
\hline Future anxiety (AQ) & Adapted from Zaleski et al. 2019 \\
\hline Perceived enjoyment (S) & Adapted from Davis et al. 1992; García et al. 2019; Poong et al. 2017 \\
\hline Service-system quality (ACI) & Adapted from Hew et al. 2018 \\
\hline Perceived ease of use & Adapted from Davis, 1989; Davis et al. 1989; Tavallaee et al. 2017; Al-Emran et al. \\
& 2020 \\
\hline Perceived usefulness & Adapted from Davis,1989; Davis et al.1989; García et al.2019; Tavallaee et al. \\
& 2017; Al-Emran et al. 2020 \\
\hline Behavioural intention & Adapted from Wang et al. 2009; Al-Emran et al. 2020; Hoi, 2020 \\
\hline
\end{tabular}

\subsection{Research model and analysis}

In this study, together with the variables of TAM, the dimensions of intrinsic leisure motivation, future anxiety, behavioural spread and system-service quality in connection with the Covid-19 pandemic process were examined as factors affecting the use of $\mathrm{m}$ learning. Accordingly, the research model was created as shown in Figure 1. The hypotheses that make up the research model are presented below. The structural equation model (SEM) used in this research is a statistical method that has become a standard tool for examining the plausibility of theoretical models that can explain the interrelationships between a set of variables in many scientific disciplines. This model stands for a series of hypotheses about how the variables in the analysis are produced and associated [29]. In this research, the LISREL program was used in structural equation model analysis. Confirmatory factor analysis is used first in the analysis of covariance structures known as the LISREL model. 


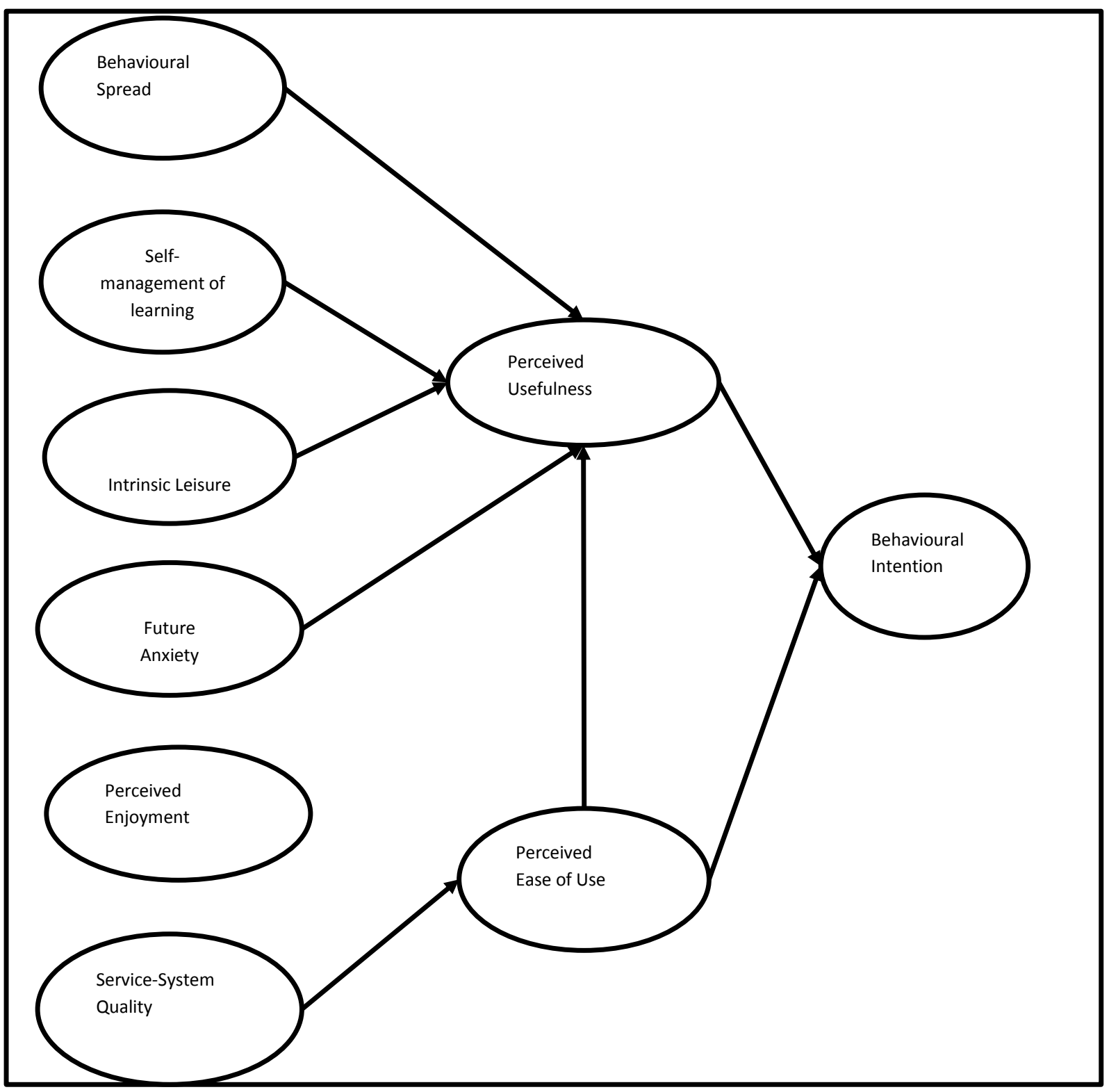

Fig. 1 Research model

The confirmatory factor model determines which common factor pairs are associated and which observed variables are affected by which common factors. It also determines which observed variables are affected by a unique factor and which unique factor pairs are associated. In this model, statistical tests are performed to determine whether the data confirms the established model [32]. The research results are submitted in Table 4:

Table 4 Opinions of the participants about m-learning

\begin{tabular}{|c|c|c|c|c|c|}
\hline & Items & Error variances & Path coefficients & t-values & Cronbach Alpha \\
\hline \multirow[t]{5}{*}{ Behavioural spread (BS) } & BS3 & 0.73 & 0.52 & 5.62 & \multirow[t]{5}{*}{,805 } \\
\hline & BS4 & 0.69 & 0.56 & 5.38 & \\
\hline & BS5 & 0.34 & 0.81 & 5.84 & \\
\hline & BS6 & 0.33 & 0.82 & 5.84 & \\
\hline & BS7 & 0.23 & 0.88 & 5.88 & \\
\hline \multirow{5}{*}{$\begin{array}{l}\text { Self-management } \\
\text { learning (SL) }\end{array}$} & SL1 & 0.68 & 0.57 & 6.36 & \multirow[t]{5}{*}{,851 } \\
\hline & SL2 & 0.55 & 0.67 & 11.20 & \\
\hline & SL3 & 0.35 & 0.81 & 12.52 & \\
\hline & SL4 & 0.25 & 0.86 & 12.91 & \\
\hline & SL5 & 0.45 & 0.74 & 11.92 & \\
\hline \multirow{4}{*}{$\begin{array}{l}\text { Intrinsic leisure motivation } \\
\text { (ILM) }\end{array}$} & ILM1 & 0.50 & 0.71 & 8.22 & \multirow[t]{4}{*}{,775 } \\
\hline & ILM2 & 0.33 & 0.82 & 15.86 & \\
\hline & ILM3 & 0.43 & 0.76 & 14.93 & \\
\hline & ILM4 & 0.47 & 0.73 & 14.46 & \\
\hline
\end{tabular}




\begin{tabular}{|c|c|c|c|c|c|}
\hline & ILM5 & 0.62 & 0.61 & 12.26 & \\
\hline \multirow[t]{5}{*}{ Future anxiety (FA) } & FA1 & 0.60 & 0.63 & 7.15 & \multirow[t]{5}{*}{,834 } \\
\hline & FA2 & 0.57 & 0.66 & 11.72 & \\
\hline & FA3 & 0.45 & 0.74 & 12.77 & \\
\hline & FA4 & 0.46 & 0.74 & 12.72 & \\
\hline & FA5 & 0.38 & 0.79 & 13.27 & \\
\hline \multirow{4}{*}{$\begin{array}{l}\text { Perceived enjoyment } \\
\text { (PE) }\end{array}$} & PE1 & 0.22 & 0.88 & 8.51 & \multirow[t]{4}{*}{, 877} \\
\hline & PE2 & 0.66 & 0.59 & 14.19 & \\
\hline & PE3 & 0.21 & 0.89 & 27.52 & \\
\hline & PE4 & 0.28 & 0.85 & 25.2 & \\
\hline \multirow{6}{*}{$\begin{array}{l}\text { Service-system quality } \\
\text { (SSQ) }\end{array}$} & SSQ1 & 0.25 & 0.87 & 6.97 & \multirow[t]{6}{*}{,934 } \\
\hline & SSQ2 & 0.27 & 0.86 & 25.30 & \\
\hline & SSQ3 & 0.29 & 0.84 & 24.53 & \\
\hline & SSQ4 & 0.33 & 0.82 & 23.40 & \\
\hline & SSQ5 & 0.38 & 0.79 & 21.85 & \\
\hline & SSQ6 & 0.29 & 0.84 & 24.46 & \\
\hline \multirow{3}{*}{$\begin{array}{l}\text { Perceived ease of use } \\
\text { (PEU) }\end{array}$} & PEU1 & 0.56 & 0.66 & 4.72 & \multirow[t]{3}{*}{,852 } \\
\hline & PEU2 & 0.34 & 0.81 & 15.88 & \\
\hline & PEU3 & 0.29 & 0.84 & 16.42 & \\
\hline \multirow{6}{*}{$\begin{array}{l}\text { Perceived usefulness } \\
\text { (PU) }\end{array}$} & PU1 & 0.44 & 0.75 & 8.43 & \multirow[t]{6}{*}{902} \\
\hline & PU 2 & 0.33 & 0.82 & 18.72 & \\
\hline & PU3 & 0.22 & 0.88 & 20.44 & \\
\hline & PU4 & 0.39 & 0.78 & 17.80 & \\
\hline & PU5 & 0.65 & 0.59 & 12.98 & \\
\hline & PU6 & 0.30 & 0.84 & 19.22 & \\
\hline \multirow{4}{*}{$\begin{array}{l}\text { Behavioural intention } \\
\text { (BI) }\end{array}$} & BI1 & 0.17 & 0.91 & 25.77 & \multirow[t]{4}{*}{,909 } \\
\hline & BI2 & 0.12 & 0.94 & 27.19 & \\
\hline & BI3 & 0.20 & 0.89 & 24.97 & \\
\hline & BI4 & 0.24 & 0.87 & 23.87 & \\
\hline
\end{tabular}

KMO test is used to determine whether the sample size is sufficient for factor analysis. As the KMO value approaches 1, the degree of excellence of the data set increases [41]. In this research, according to the analysis result, the KMO value was found as 0.955 . Therefore, the sample size considered in the study is quite sufficient. Path analysis allows dividing simple correlations between a set of variables according to a particular study model about causal relationships [33]. Moreover, the path coefficients of 0.45 and above are considered a sufficient criterion for the study [17]. It is seen that the factor loadings in the analysis range between 0 . and 0.94 . However, since the factor load of the expressions BS1 (0.17), BS2 (0.38), ILM5 (0.17) was below 0.45, they were excluded from the scale. The variance, which is explained as an indicator that the structure of interest in the study has been well measured, should be above 0.50 [24]; [15]. The total variance $(\%)$ explained in this study is 68,232 . Reliability is a measure that reflects the internal consistency reliability between the indicators of each structure, how well a set of instrument items selected for a particular structure measure the same structure and consistency in different situations. For this study, the Cronbach Alpha value was used to analyze whether a certain structure is independent of other structures [39]. A reliability coefficient of Cronbach's Alpha value of $70 \%$ or higher is considered an "acceptable" value in most social science research [7]. As a result, all dimensions in this study are acceptable according to the results of the reliability analysis.

The SEM technique starts with the specification of the model to be estimated. Evaluating the goodness of fit and estimating the parameters of the assumed model are the primary goals. Absolute fit indices determine how well the model fits the sample data [29]. The fit indices of the research model are presented in Table 5:

Table 5 The goodness of fit indexes and structural model of the research model

\begin{tabular}{|l|l|l|}
\hline Constructs & Acceptability Criteria & Values derived from the model \\
\hline x2/sd & $1<\mathrm{x} 2<5$ & $2743.66 / 980=2,79$ \\
\hline RMSEA (Root Mean Square Error of Approximation) & $0.05 \leq \mathrm{RMSEA} \leq 0,08$ & 0.066 \\
\hline GFI (Goodness of Fit Index) & $\mathrm{GFI} \geq 0.95$ & 0,79 \\
\hline AGFI (Adjusted Goodness of Fit Index) & $\mathrm{AGFI} \geq 0,95$ & 0,76 \\
\hline NFI (Normed Fit Index) & $\mathrm{NFI} \geq 0,97$ & 0,96 \\
\hline NNFI (Non-Normed Fit Index) & $\mathrm{NNFI} \geq 0,97$ & 0,97 \\
CFI (Comparative Fit Index) & $\mathrm{CFI} \geq 0,97$ & 0,97 \\
RMR (Root Mean Square Residual) & $\mathrm{RMR} \leq 0.05$ & 0,12 \\
SRMR (Standardized RMR) & $0.05<\mathrm{SRMR} \leq 0.10$ & 0,088 \\
\hline
\end{tabular}

When Table 5 is examined, it is seen that all values are in the acceptable range of goodness of fit. So, it can be stated that the research model is generally confirmed by the data. The results of the research model are presented in Table 6: 


\section{Table 6 Results of the research model}

\begin{tabular}{|c|c|c|c|c|}
\hline Hypothesis & Causal path & $\begin{array}{l}\text { Standardized } \\
\text { path } \\
\text { coefficient }\end{array}$ & $\mathbf{R}^{2}$ & $\begin{array}{l}\mathrm{t}- \\
\text { values }\end{array}$ \\
\hline $\begin{array}{l}\text { H1 } \\
\text { H2 } \\
\text { H3 } \\
\text { H4 } \\
\text { H5 } \\
\text { H6 } \\
\text { H7 } \\
\text { H8 } \\
\text { H9 }\end{array}$ & $\begin{array}{l}\mathrm{BS} \cdot \mathrm{PU} \\
\mathrm{SL} \cdot \mathrm{PU} \\
\mathrm{ILM} \cdot \mathrm{PU} \\
\mathrm{FA} \cdot \mathrm{PU} \\
\mathrm{PE} \cdot \mathrm{PEU} \\
\mathrm{SSQ} \cdot \mathrm{PEU} \\
\mathrm{PEU} \cdot \mathrm{PU} \\
\mathrm{PU} \cdot \mathrm{BI} \\
\mathrm{PEU} \cdot \mathrm{BI}\end{array}$ & $\begin{array}{l}0,50 \\
0.50 \\
0.48 \\
-0.17 \\
0.89 \\
0.94 \\
0.70 \\
0.82 \\
0.31\end{array}$ & $\begin{array}{l}0.25 \\
0.25 \\
0.23 \\
0.028 \\
0.79 \\
0.88 \\
0.93 \\
0.68 \\
0.77\end{array}$ & $\begin{array}{l}5.17 \\
8,31 \\
8.81 \\
-3.25 \\
15.59 \\
16.05 \\
11.25 \\
15.94 \\
6.76\end{array}$ \\
\hline
\end{tabular}

Table 6 shows the results of the SEM analysis of the structural model. Perceived usefulness and perceived ease of use had a significant effect on m-learning behavioural intention $(=0.82, p$ $<0.01 ; \beta=0.31, \mathrm{p}<0.01)$. These results support the H8 and H9 hypotheses. Perceived ease of use has the greatest effect on mlearning behavioural intention and explains the behavioural intention $\left(\mathrm{R}^{2}=0.77\right)$ by $77 \%$. Perceived usefulness m-learning explains $68 \%$ of behavioural intention $\left(\mathrm{R}^{2}=0.68\right)$. Besides, behavioural spread and self-management of learning affect perceived usefulness at the same level $(\beta=0.50, \mathrm{p}<0.01 ; \beta=0.50$, $\mathrm{p}<0.01)$ and explain $25 \%$ of perceived usefulness $\left(\mathrm{R}^{2}=0.25\right)$. Intrinsic leisure motivation $\left(\mathrm{R}^{2}=0.23\right)$ explains the perceived usefulness at the least $23 \%$. Accordingly, the $\mathrm{H} 1, \mathrm{H} 2$ and $\mathrm{H} 3$ hypotheses were also supported. The $\mathrm{H} 4$ hypothesis was rejected because of future anxiety $(=0.028, \mathrm{p}>0.01)$. Service-system quality and perceived enjoyment affect perceived ease of use (= $0.94, \mathrm{p}<0.01 ; \beta=0.89, \mathrm{p}<0.01)$. Service-system quality $\left(\mathrm{R}^{2}=\right.$ 0.88 ) explains $88 \%$ perceived ease of use. Also, perceived enjoyment explains the perceived ease of use by $79 \%$. These findings support the $\mathrm{H} 5$ and $\mathrm{H} 6$ hypotheses.

\section{Conclusion}

As the most important learning model of today and the future, mlearning simplifies the adaptation of both business life staff, students and individuals who want to invest in themselves to changing and developing world conditions. M-learning is a learning-centred environment that enables individuals to learn, experience, discover and interact. Thanks to m-learning, every individual can find the opportunity to improve themselves according to their field of expertise. Making lifelong learning skills a routine is an indicator of the importance of m-learning.

A behavioural spread involves the transmission of thought to certain segments and thus the spread of behavioural intentions and purchases. In this study, it was concluded that behavioural spread affects perceived usefulness by considering both social impact and peer effect. [1];[11]; [48]; [31] show in their study that social influence is among the important factors of behavioural intention to use m-learning and affects behavioural intention.

[1], in their 2019 study on self-management of learning, found that self-management of m-learning negatively affected students' behavioural intention or usage behaviour. [48] found learning to learn as a significant predictor of behavioural intention to use mlearning in their study. In this study, unlike the results in the literature, it was revealed that self-management of learning significantly affects the perceived usefulness. During the pandemic process, it is thought that the skills of individuals such as selfmanagement, discipline, time management, developing critical thinking, and determining learning goals have increased. So, in the future m-learning environments, individuals will be able to selfmanage at a high level to be successful.

There are psychological and sociological factors underlying the participation of individuals in leisure events during the pandemic process. At the heart of these factors is the internal leisure motivation that forms the pleasure-based element taken from the time, effort and process. The intrinsic leisure motivation factor, which includes the effective and efficient utilization of leisure time, affects the perceived usefulness, thus on the m-learning behavioural intention, as predicted in this study.

In this study, the future anxiety is presented with the idea that individuals' concerns about the future will be at the forefront during the pandemic process, they will maybe feel afraid of future events and that there may be dangerous or negative changes in the future. It is a surprising result that the presented future anxiety factor does not effect perceived usefulness, thus on m-learning behavioural intention.

[25] found that perceived enjoyment is a powerful predictor of perceived ease of use in m-learning. [38] show that perceived enjoyment directly affects behaviours of using m-learning. In this study, individuals who enjoy m-learning will increase their interest when they like m-learning environments and they will perceive it as easy to use and develop a positive attitude towards their behavioural intentions.

[28] concluded that system-service quality in mobile tourism applications has moderate effects on perceived ease of use. In this study, it is seen that service-system quality has a significant effect on m-learning behavioural intention. It was concluded that service providers should emphasize on the factors such as website quality, the usability of the system, the fulfilment of their promises, correct communication, ability to respond, compensatory ability, effectiveness, and interaction with the user.

[25] stated that perceived ease of use is the strongest determinant of perceived usefulness in m-learning. [3] stated in their study that ease of use may lead to developing students' behavioural intentions about using the m-learning application. [38] stated that perceived ease of use directly affects the behaviours of using m-learning. Besides, [38] concluded that perceived usefulness directly affects behaviours of using m-learning. [3] found that perceived usefulness improves students' behavioural intentions to use the m-learning application. [25] stated that perceived usefulness is the most important premise of behavioural intention and hence acceptance of m-learning. He concluded that perceived usefulness was a more important factor than perceived ease of use for determining behavioural intention, as well as acting as a mediator between the two structures. [39] concluded that perceived ease of use is the most important factor compared to the perceived usefulness for using m-learning. In this study, a result was obtained that supports the result found by [39].

Mobile learning perspectives and features for mobile learning should be recognized and considered more by researchers and practitioners. By frankly defining the unique functions and possibilities of this rapidly changing field in educational technology, it is possible to influence future educational research in a meaningful way.

The consistency of all findings provides important implications for both research and application. This study contributed to the confirmation of the extended TAM model for a mobile device. For 
the researchers, this study took an important step towards explaining the m-learning relationship with students' intrinsic leisure motivation, future anxiety, behavioural spread, and systemservice quality learning perspectives. For future research, it can be suggested that the subject of m-learning should be researched using different models and expanded with other external variables related to examining the model. The universe can be applied to different groups. Furthermore, to test these results that occur during the pandemic period, it may be suggested to remake the research when the pandemic process is over and to examine whether this trend towards m-learning continues with a longitudinal study.

Educators should develop more sophisticated m-learning concepts that increase motivation for students to broaden their learning profiles and approaches. Significantly, m-learning system designers pay attention to improving the systemic quality of the mobile learning system as it includes features such as userfriendliness, easy accessibility and reliability. Better quality can only be maintained through continuous quality improvement.

Efforts are recommended for marketing managers to adapt to today's mobile environment and to improve m-learning services usage behaviour.

\section{Data Availability}

The original contributions presented in the study are included in the article, further inquiries can be directed to the corresponding author.

\section{Conflicts of Interest}

The authors declares that there is no conflict of interest regarding the publication of this paper.

\section{References}

[1] Alasmari, T. and Zhang, K. (2019). "Mobile learning technology acceptance in Saudi Arabian higher education: an extended framework and A mixed-method study", Education and Information Technologies, Vol.24 No.3, pp. 2127-2144.

[2] Almaiah, M. A., Alamri, M. M. and Al-Rahmi, W. (2019). "Applying the UTAUT Model to Explain the Students' Acceptance of Mobile Learning System in Higher Education", IEEE Access, Vol.7 No.4, pp. 174673-174686.

[3] Almaiah, M. A., Jalil, M. A. and Man, M. (2016). "Extending the TAM to examine the effects of quality features on mobile learning acceptance", Journal of Computers in Education, Vol.3 No.4, pp.453-485.

[4] Ali, R. A. and Arshad, M. R. M. (2016). "Perspectives of students' behavior towards mobile learning (M-learning) in Egypt: an extension of the UTAUT model", Engineering, Technology and Applied Science Research, Vol.6 No.4, pp. 1109-1114.

[5] Aliaño, Á. M., Hueros, A. D., Franco, M. G. and Aguaded, I. (2019). "Mobile learning in university contexts based on the unified theory of acceptance and use of technology (UTAUT)", Journal of New Approaches in Educational Research (NAER Journal), Vol.8 No.1, pp. 7-17.
[6] Aloqaily, A. A., Al-Nawayseh, M. K., Baarah, A. H., Salah, Z., Al-Hassan, M. and Al-Ghuwairi, A. R. (2019). "A neural network analytical model for predicting determinants of mobile learning acceptance", IJCAT, Vol.60 No.1, pp. 73-85.

[7] Alsamydai, M., J. (2014). "Adaptation of the Technology Acceptance Model (TAM) to the Use of Mobile Banking Services", International Review of Management and Business Research, Vol.3 No.4, pp. 2031-2051.

[8] Alshurideh, M. T., Salloum, S. A., Al Kurdi, B., Monem, A. A. and Shaalan, K. (2019). "Understanding the quality determinants that influence the intention to use the mobile learning platforms: A practical study", International Journal of Interactive Mobile Technologies (IJIM), 13(11), 157-183.

[9] Altrad, A. M. M. (2017). "Determine Factors Influencing Mobile Learning Acceptance in Higher Education Institution of Malaysia: Online Based Learning", International Journal on Contemporary Computer Research (IJCCR), Vol.1 No.1, pp. 43-49.

[10] Aofan, L., Zhang, Y., Qianqian, C. and Chang, T. (2016). "Investigating the Determinants of Mobile Learning Acceptance in Higher Education Based on UTAUT", 2016 International Computer Symposium, pp.651-655.

[11] Arain, A. A., Hussain, Z., Rizvi, W. H. and Vighio, M. S. (2019). "Extending UTAUT2 toward acceptance of mobile learning in the context of higher education", Universal Access in the Information Society, Vol.18 No.3, pp. 659-673.

[12] Al-Emran, M., Mezhuyev, V. and Kamaludin, A. (2020). "Towards a conceptual model for examining the impact of knowledge management factors on mobile learning acceptance", Technology in Society, 101247.

[13] Al-Shihi, H., Sharma, S. K. and Sarrab, M. (2018). "Neural network approach to predict mobile learning acceptance", Education and Information Technologies, Vol.23 No.5, pp.1805-1824.

[14] Al-Zoubi, M. (2016). "Factors That Influence Mobile Learning Acceptance in Higher Education Institutions in Dubai", Account and Financial Management Journal, Vol.1, pp. 392-400.

[15] Büyüköztürk, Ş. (2002). “Faktör Analizi: Temel Kavramlar ve Ölçek Geliştirmede Kullanımı”, Kuram ve Uygulamada Eğitim Yönetimi Dergisi, Vol.32, pp. 47048.

[16] Chavoshi, A. and Hamidi, H. (2019). "Social, individual, technological and pedagogical factors influencing mobile learning acceptance in higher education: A case from Iran", Telematics and Informatics, Vol.38, pp. 133-165.

[17] Comrey, A. and Lee, H. (1992). A First Course in Factor Analysis, Hillsdale, NJ: Erlbaum.

[18] Davis, F. D. (1989). "Perceived usefulness, perceived ease of use, and user acceptance of information technology", MIS quarterly, pp.319-340.

[19] Davis, F., D. and Venkatesh, V. 1996. "A critical assessment of potential measurement biases in the Technology Acceptance Model: Three experiments", Int . J . Human - Computer Studies, Vol.45, pp. 19 - 45.

[20] Davis, F.D., Bagozzi, R.P. and Warashaw, P., R. (1992) "Extrinsic and intrinsic motivation to user computers in the workplace", Journal of Applied Social Psychology, Vol.22 No.14, pp.1111-1132. 
[21] Davis, F.,D., Bagozzi, R.,P. and Warshaw, P.,R. (1989). "User acceptance of computer technology: a comparison of two theoretical models", Management science, Vol.35 No.8, pp.982-1003.

[22] Edwards Jr, J. R. (2017). Undergraduate Student Acceptance and Use of Mobile Learning in Speech Preparation Using Skype (Doctoral dissertation, Indiana State University).

[23] El-Ebiary, Y. A. B., Alzubi, M. M. and Al-Sammarraie, N. A. (2017). Determinants of Mobile Learning Acceptance among Student at Al-Madinah International University in Malaysia.

[24] Fornell, C. and Larcker, D. (1981). "Evaluating Structural Equation Models with Unobservable Variables and Measurement Error", Journal of Marketing Research, Vol.18 No.1, pp. 39-50.

[25] García, M. V., López, M. F. B. and Castillo, M. Á. S. (2019). "Determinants of the acceptance of mobile learning as an element of human capital training in organisations", Technological Forecasting and Social Change, 149, 119783.

[26] Hoi, V. N. (2020). "Understanding higher education learners' acceptance and use of mobile devices for language learning: A Rasch-based path modeling approach", Computers and Education, 146, 103761.

[27] Hao, S., Dennen, V. P., and Mei, L. (2017). "Influential factors for mobile learning acceptance among Chinese users", Educational Technology Research and Development, Vol.65 No.1, pp. 101-123.

[28] Hew, J. J., Leong, L. Y., Tan, G. W. H., Lee, V. H., and Ooi, K. B. (2018). "Mobile social tourism shopping: A dual-stage analysis of a multi-mediation model", Tourism Management, 66, 121-139.

[29] Hu, L. and Bentler, P., M. (1999) "Cutoff criteria for fit indexes in covariance structure analysis: Conventional criteria versus new alternatives", Structural Equation Modeling: A Multidisciplinary Journal, Vol.6 No.1, pp. $1-55$.

[30] Huang, R. T., Yu, C. L., Tang, T. W. and Chang, S. C. (2019). "A study of the use of mobile learning technology in Taiwan for language learning", Innovations in Education and Teaching International, 113.

[31] Kang, M., Liew, B. Y. T., Lim, H., Jang, J. and Lee, S. (2015). "Investigating the determinants of mobile learning acceptance in Korea using UTAUT2", In Emerging issues in smart learning (pp. 209-216). Springer, Berlin, Heidelberg.

[32] Long, J., S. (1983). Confirmatory Factor Analysıs, Sage Publication, Newbury: America.

[33] Mitchell, R.,J. (1992). "Testing evolutionary and ecological hypotheses using path analysis and structural equation modelling", Functional Ecology, 123-129

[34] Mutlu, İ. (2008). Egzersiz yapan kişilerin boş zamanlarına yönelik tutumları üzerine bir araştırma (Kayseri İli Örneği). Niğde Üniversitesi Sosyal Bilimler Enstitüsü, Yayımlanmamış Yüksek Lisans Tezi, Niğde.

[35] Mutono, A. and Dagada, P. (2016). "Learners' Acceptance of Mobile Learning for Post-School Education and Training in South Africa", Current Journal of Applied Science and Technology, 1-10.

[36] Özdemir, A. S., Durhan, T. A. and Karaküçük, S. (2020). "İçsel Boş Zaman Motivasyon Ölçeği Geçerlilik ve
Güvenirlik Çalışması", OPUS Uluslararası Toplum Araştırmaları Dergisi, Vol.16 No.24, pp. 1-1.

[37] Park, SY, Nam, M.W., and Cha, S.B. (2012). "University students' behavioral intention to use mobile learning: Evaluating the technology acceptance model", British Journal of Educational Technology, Vol.43 No.3, pp. 592-605.

[38] Park, S. Y., Lee, H. D. and Kim, S. Y. (2018). "South Korean university students' mobile learning acceptance and experience based on the perceived attributes, system quality and resistance", Innovations in Education and Teaching International, Vol.55 No.4, pp. 450-458.

[39] Poong, Y. S., Yamaguchi, S. and Takada, J. I. (2017). "Investigating the drivers of mobile learning acceptance among young adults in the World Heritage town of Luang Prabang, Laos", Information Development, Vol.33 No.1, pp. 57-71.

[40] Sabah, N. M. (2016). "Exploring students' awareness and perceptions: Influencing factors and individual differences driving m-learning adoption", Computers in Human Behavior, 65, 522-533.

[41] Sharma, S.C. (1996), Applied Multivariate Techniques. John Wiley and Sons., New York.

[42] Saroia, A. I. and Gao, S. (2019). "Investigating university students' intention to use mobile learning management systems in Sweden", Innovations in Education and Teaching International, Vol.56 No.5, pp. 569-580.

[43] Sharma, S. K., Sarrab, M. and Al-Shihi, H. (2017). "Development and validation of Mobile learning acceptance measure", Interactive Learning Environments, Vol.25 No.7, pp. 847-858.

[44] Senaratne, S. I., Samarasinghe, S. M., and Jayewardenepura, G. (2019). "Factors affecting the intention to adopt m-learning", International Business Research, Vol.12 No.2, pp. 150-164.

[45] Seth, A., Coffie, A., J., Richard, A., Stephen, S., A. 2019. "Hospital administration management technology adoption; A theoretical test of technology acceptance model and theory of planned behavior on HAMT adoption", American Journal of Public Health Research, Vol.7 No.1, pp. 21-26.

[46] Tabachnick, B. G., Fidell, L. S. and Ullman, J. B. (2007). Using multivariate statistics (Vol. 5). Boston, MA: Pearson.

[47] Tavallaee, R., Shokouhyar, S. and Samadi, F. (2017). "The combined theory of planned behaviour and technology acceptance model of mobile learning at Tehran universities", International Journal of Mobile Learning and Organisation, Vol.11 No.2, pp. 176-206.

[48] Uğur, N. G., Koç, T. and Koç, M. (2016). "An analysis of mobile learning acceptance by college students", Journal of Educational and Instructional Studies in the World, 6(2).

[49] Vahdat, A., Alizadeh, A., Quach, S. and Hamelin, N. (2020). "Would you like to shop via mobile app technology? The technology acceptance model, social factors and purchase intention", Australasian Marketing Journal (AMJ).

[50] Venkatesh, V., Morris, M., G., Davis, G.,B., Davis, F.,D. (2003) "User acceptance of information technology: Toward a unified view", MIS quarterly: 425-478 
[51] Yeap, J. A., Ramayah, T. and Soto-Acosta, P. (2016). "Factors propelling the adoption of m-learning among students in higher education", Electronic Markets, Vol.26 No.4, pp. 323-338.

[52] Zaleski, Z., Sobol-Kwapinska, M., Przepiorka, A. and Meisner, M. (2019). "Development and validation of the
Dark Future scale", Time and Society, Vol.28 No.1, pp. 107-123.

[53] Wang, Y. S., Wu, M. C. and Wang, H. Y. (2009). "Investigating the determinants and age and gender differences in the acceptance of mobile learning", British journal of educational technology, Vol.40 No.1, pp. 92118. 